\title{
Naturally Occurring Radioactive Materials (NORM) in Produced Water and Oil-Field Equipment- An Issue for the Energy Industry
}

\section{Introduction}

Naturally occurring radioactive elements such as uranium, radium, and radon are dissolved in very low concentrations during normal reactions between water and rock or soil. Ground water that coexists with deposits of oil can have unusually high concentrations of dissolved constituents that build up during prolonged periods of water/rock contact. Many oil-field waters are particularly rich in chloride, and this enhances the solubility of other elements including the radioactive element radium. Some of this saline, radium-bearing water is unavoidably brought to the Earth's surface with the oil and must be separated and then disposed, usually by return to depth in an injection well. At some oil-field sites the pipes and tanks that handle large volumes of this "produced water" can become coated with scale deposits that contain radium. Radiumbearing scale is the type of "diffuse NORM waste" that occurs in the oil industry. Radium accumulation in oil-field equipment in the United States first became apparent in the 1980's when scrap metal dealers began to routinely detect unacceptable levels of radioactivity in shipments of oil-field pipe. Since that time the oil and gas industry has sought to better define the extent of the oilfield NORM problem, and to develop techniques for the prediction, prevention, remediation, and disposal of oil-field NORM. In parallel efforts, State and Federal regulatory agencies have worked to develop guidelines for the control of NORM that will adequately protect public health and the environment. This report summarizes current understanding of the composition and mode of occurrence of oil-field NORM in the United States, briefly reviews the status of NORM regulations, and identifies some health and environmental issues associated with oil-field NORM.

\section{Location of Oil-Field NORM in the United States}

Deposits of oil are found in 30 States, but the vast majority (86 percent) of onshore oil production is concentrated in Texas, Oklahoma, Louisiana, Wyoming, California, Kansas, and New Mexico (fig. 1A). In 1989 the American Petroleum Institute sponsored a preliminary nationwide reconnaissance of measurable radioactivity at the exterior surfaces of oil-field equipment (Otto, 1989). The results of this nonstatistical sampling indicated that gamma-ray radiation levels exceeded natural background radiation levels at 42 percent of the sites. Radiation levels greater than five times the median background of all sites were found at approximately 10 percent of the sites. Most of the sites with markedly higher radioactivity were concentrated in specific geographical areas, such as the Gulf Coast, northeast Texas, southeast Illinois, and south-central Kansas (fig. 1B). Additional surveys by some State agencies identified radioactive oil-field equipment in northern Michigan and eastern Kentucky. Pipe, casing, fittings, and tanks that have an extended history of contact with produced water are more likely to contain radioactive deposits than other parts of the plumbing system at oil-field production

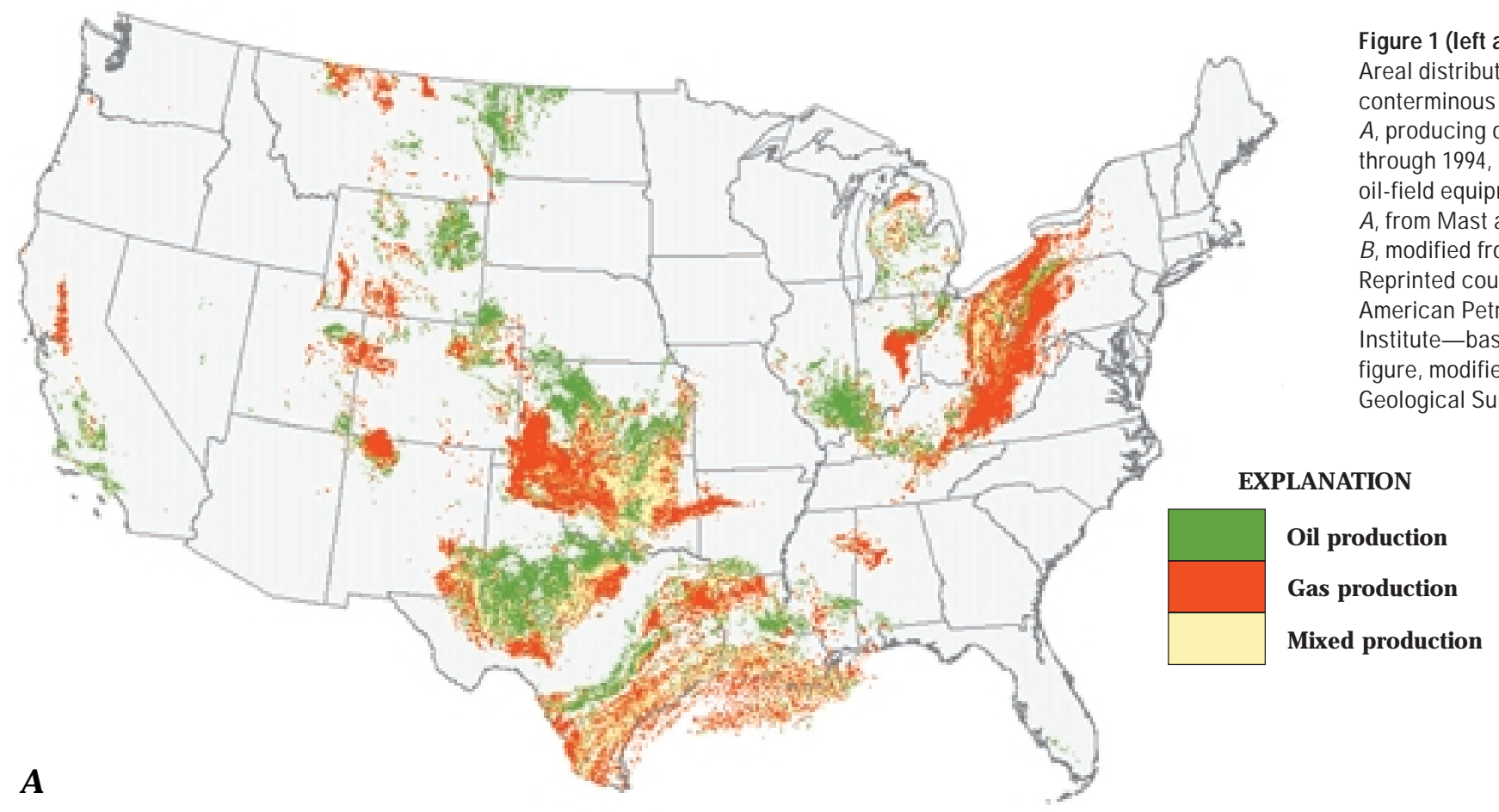




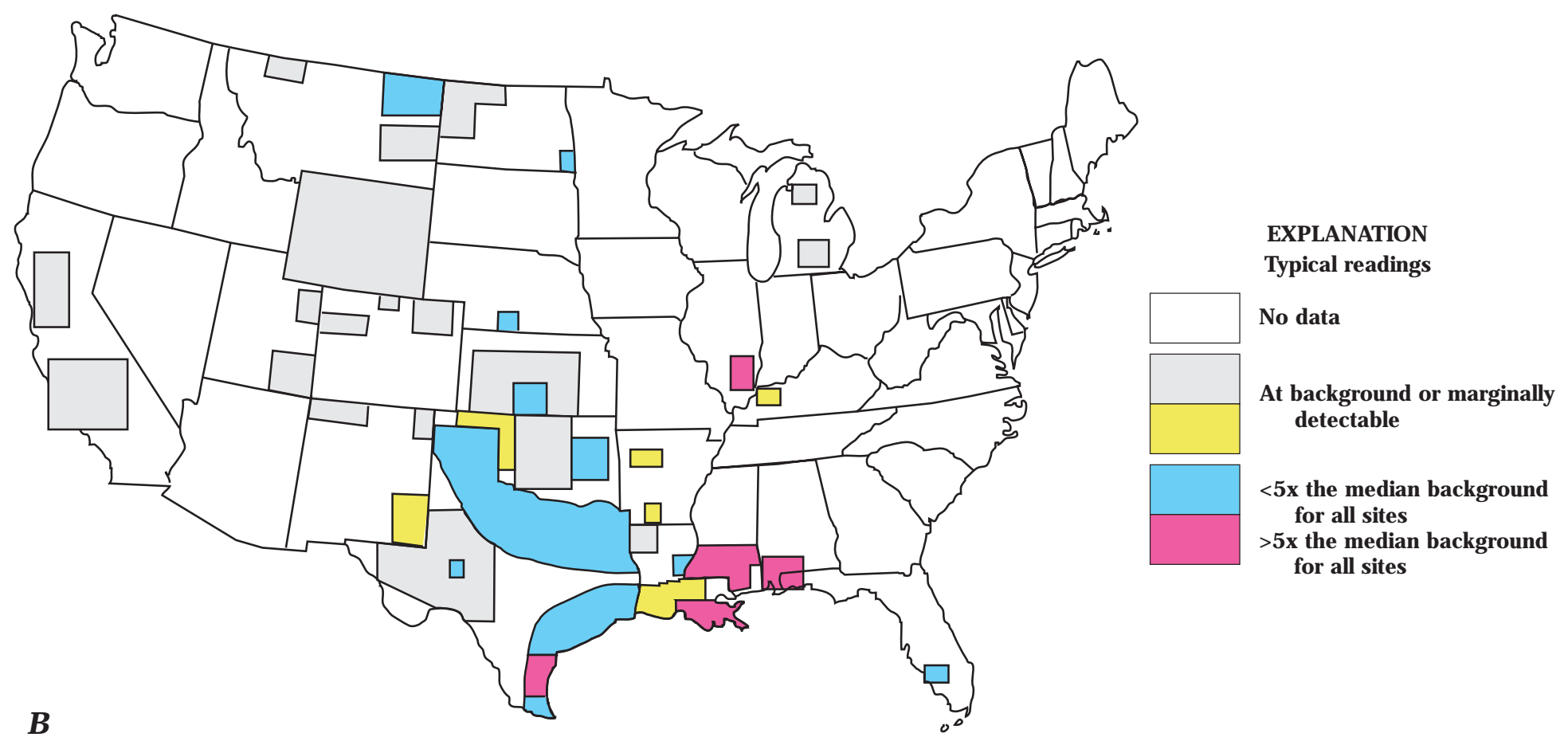

sites. Soil in the immediate vicinity of production sites may be unusually radioactive if affected by spills or leakage of produced water, or if contaminated by scale removed during pipe or tank cleaning operations. Handling of used pipe at pipe storage yards may also contaminate soil with radioactive scale. Although not discussed herein, some equipment used to process and transport natural gas may contain small amounts of radioactive decay products of radon gas.

\section{Form of Oil-Field NORM}

Oil-field equipment can contain radioactive scale and scale-bearing sludge, both of which form as coatings or sediments. The scale precipitates from produced water in response to changes in temperature, pressure, and salinity as the water is brought to the surface and is processed to separate coexisting crude oil. The scale is typically a mixture of carbonate and sulfate minerals. One of these sulfate minerals is barite (barium sulfate), which is known to readily incorporate radium $(\mathrm{Ra})$ in its structure. Many studies of radioactive scale from oil-field equipment have documented that barite is the primary host of oil-field NORM and that the radioactivity is from isotopes of radium and their decay products. The two radium isotopes present in produced water and barite scale are ${ }^{226} \mathrm{Ra}$ (half-life $=1,600$ years) and ${ }^{228} \mathrm{Ra}$ (half-life $=5.8$ years). These two isotopes are produced by radioactive decay of uranium and thorium present in rocks of the oil-producing formations. The concentration of dissolved radium is therefore influenced by the abundance of uranium and thorium in reservoir rock and by the accessibility of water to the sites containing uranium and thorium. When radium is brought to the surface in produced water, the concentration of radium that is incorporated in barite scale is largely a function of (1) the concentration of dissolved radium and (2) the amount of produced water that moves past the site of barite precipitation.

Ongoing studies by USGS scientists are documenting variations in the mineralogy, chemistry, and radium concentration of in-place scale deposits. Better understanding of the specific location and texture of the most radioactive barite scale should contribute to more cost-effective strategies for its removal. Figure $2 A$ illustrates some of the textural and mineralogical variability in a sample of scale from an old section of aboveground oil-field pipe. Lighter colored barite is present along with variable amounts of darker iron oxides. Barite occurs as intact layers as well as fragments of former layers that were transported and recemented with iron oxides. A corresponding image of radioactivity in this sample (fig. $2 B$ ) is recorded on a special film and illustrates the variable concentration of radium and its radioactive decay products in these layers.

\section{Abundance of Radium in Oil-Field NORM}

Measurement of total radioactivity with a hand-held radiation detection instrument permits rapid assessment of a site for NORM contamination, but site cleanup criteria and waste disposal options are based on actual concentrations of radium isotopes. Some specialized field instruments permit rapid estimates of the concentration of radium isotopes, but such estimates require confirmation by careful laboratory analysis of selected subsets of samples. Radium concentrations are generally reported as picocuries/gram ( $\mathrm{pCi} / \mathrm{g}$ ) of solid material or picocuries/liter $(\mathrm{pCi} / \mathrm{L})$ of water or air. A picocurie equals 2.22 disintegrations-per-minute (dpm). Figure $3 A$ illustrates the distribution of total radium concentration $\left({ }^{226} \mathrm{Ra}\right.$ and $\left.{ }^{228} \mathrm{Ra}\right)$ in barrels of oil-field NORM waste stored in Louisiana in 1992 (Wascom, 1994). The maximum radium concentration in this waste and in most reported oil-field scale from the U.S. is several thousand $\mathrm{pCi} / \mathrm{g}$, although very small quantities of scale have been reported with as much as 400,000 $\mathrm{pCi} / \mathrm{g}$ of radium. For comparison, most natural soils and rocks contain approximately $0.5-5 \mathrm{pCi} / \mathrm{g}$ of total radium. A uranium ore sample containing 1 weight percent uranium has approximately $3,300 \mathrm{pCi} / \mathrm{g}$ of ${ }^{226} \mathrm{Ra}$. Most of the radium in older oil-field scale is ${ }^{226} \mathrm{Ra}$, because the shorter lived ${ }^{228} \mathrm{Ra}$ decays with a half-life of 5.8 years.

Figure $3 B$ illustrates the distribution of dissolved ${ }^{226} \mathrm{Ra}$ concentration in 215 samples of produced water from seven major oil-producing areas (Fisher, 1998). Radium tends to be more 
abundant in the more saline and chloride-rich varieties of these produced waters. The maximum concentration of dissolved ${ }^{226} \mathrm{Ra}$ in this limited data set is several thousand $\mathrm{pCi} / \mathrm{L}$, but concentrations above $10,000 \mathrm{pCi} / \mathrm{L}$ have been reported in the U.S. Produced water also contains dissolved ${ }^{228} \mathrm{Ra}$, which is typically one-half to twice the concentration of ${ }^{226} \mathrm{Ra}$. For comparison, the U.S. EPA maximum contaminant level for drinking water is $5 \mathrm{pCi} / \mathrm{L}$ for total dissolved radium.

\section{Regulations for the Control of Oil-Field NORM}

There currently exist no Federal regulations that specifically address the handling and disposal of oil-field NORM wastes. States that have enacted specific NORM regulations include some important oil producers such as Texas, Louisiana, New Mexico, and Mississippi. New NORM regulations or modifications to general radiation protection statutes are under consideration in
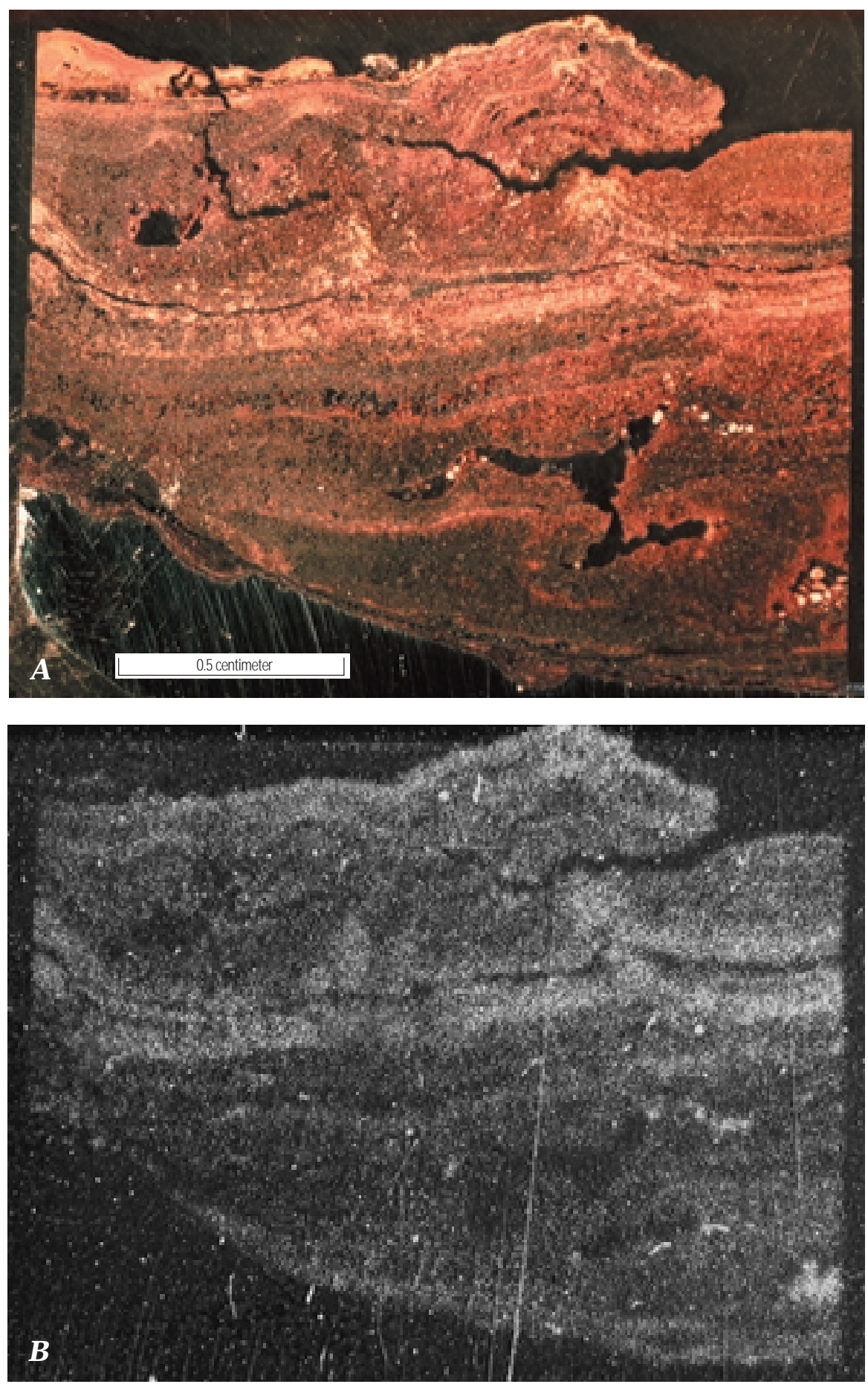

Figure 2. Radioactive scale deposits inside oil-field pipe $(A)$ and the distribution of alpha-particleemitting radium and radium decay products in the same sample $(B)$. Brighter regions on the alpha emission image indicate areas of scale with higher concentrations of radioactive elements. other major oil-producing States such as California, Kansas, and Oklahoma. Standards for cleanup of radium-contaminated soils that typically appear in enacted or proposed NORM regulations call for an average concentration of less than $5 \mathrm{pCi} / \mathrm{g}$ in the upper $15 \mathrm{~cm}$ (centimeters) of soil and an average of less than $15 \mathrm{pCi} / \mathrm{g}$ in deeper increments of $15 \mathrm{~cm}$. Some States allow an average of as much as 30 $\mathrm{pCi} / \mathrm{g}$ of radium in the upper $15 \mathrm{~cm}$ of soil. For oilfield equipment, typical standards for release for other uses or for recycling require that radioactivity at the surface should not exceed some low multiple of natural background radioactivity.

\section{Health and Environmental Issues of Oil-Field NORM}

Once formed, barite is a very insoluble mineral. One liter of water at the Earth's surface dissolves only 0.0025 grams of barite. Efficient removal of barite deposits from oil-field equipment requires special chemicals or vigorous mechanical methods. The process of barite removal and disposal is complicated by the need to minimize radiation dose to workers and the general public. Radiation exposure pathways include external gamma radiation (major), ingestion (minor), and inhalation of particulates and radon gas (major).

Figure 4 illustrates the relative isolation of NORM waste from the general public for a variety of possible disposal options. As degree of isolation increases so does the capability for disposing of higher radium concentrations. Currently most oilfield NORM waste is stored at production sites awaiting disposal in specially designated and permitted landfills, disposal wells, or injection wells (fig. 4). Surface spreading and dilution of low-level NORM waste (fig. 4) is a past practice that is now disallowed by most States with NORM regulations. A preliminary radiological dose assessment was reported for a scenario in which individuals live on a NORM-amended soil and consume local water, livestock, and food crops (Smith and others, 1996). For soils amended with radium to the highest concentration under regulatory consideration (30 $\mathrm{pCi} / \mathrm{g}$ ) the additional annual radiation dose by all pathways was equivalent to the average annual background dose to the U.S. population. Current limits set by the Nuclear Regulatory Commission require that the total of such additional doses to the general public be limited to about 30 percent of the average annual background dose.

Prior to 1970 the regulations governing disposal of produced water and scale were less restrictive, and thus older oil-field production sites are more likely to have above-background concentrations of NORM in nearby soils and stream sediments. Several studies, including some by USGS researchers, have documented the presence of barite in soils contaminated with oilfield NORM. 


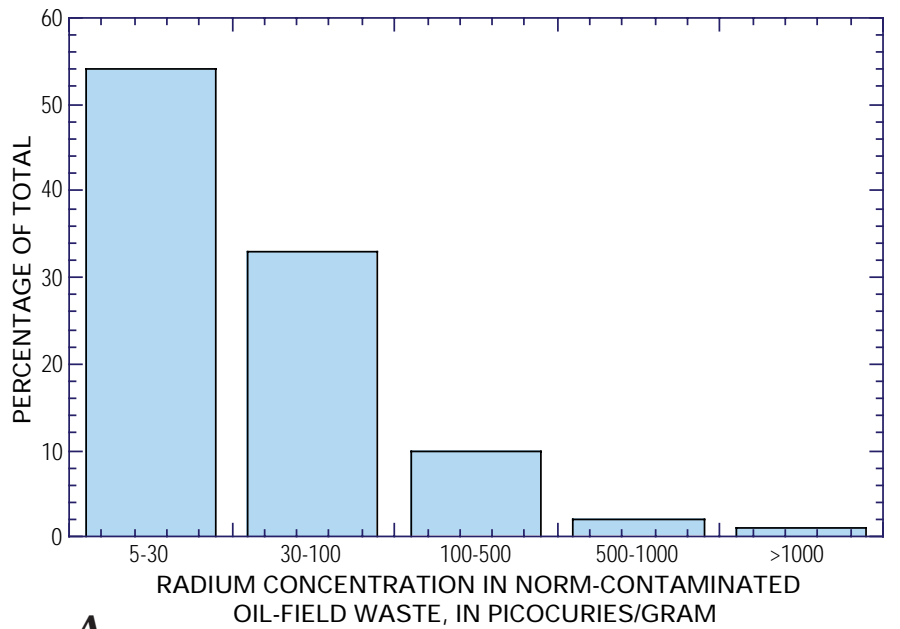

A

OIL-FIELD WASTE, IN PICOCURIES/GRAM

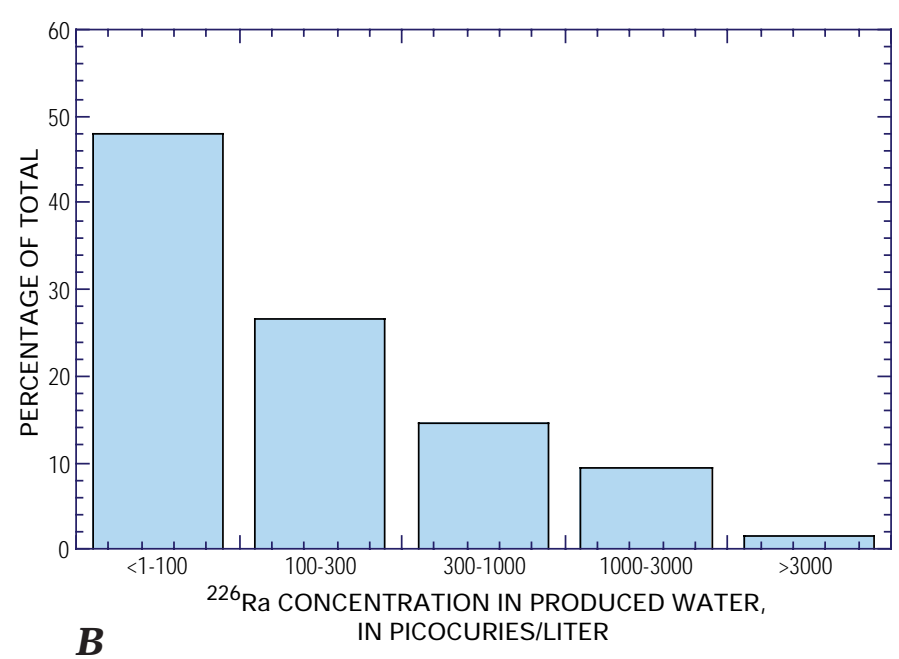

Figure 3. Estimated distribution of radium concentration in $A$, solid oil-field waste and $B$, produced water.

Figure 4. Disposal alternatives for NORM wastes. Disposal of more concentrated wastes requires greater isolation of waste from the general public. Modified from American Petroleum Institute (1992). Reprinted courtesy of the American Petroleum Institute- based on original API figure, modified by U.S. Geological Survey.

Barite scale is the most likely host of elevated radium in these soils. The extreme insolubility of barite under natural conditions limits the rate of release of radium to water and suggests that dispersal of radium will be dominated by physical transport of barite particles. Barite solubility is lowest in oxidized soils that are rich in sources of soluble sulfate such as gypsum. In organic-rich soils barite solubility is increased by the action of sulfate-consuming bacteria. The average age of formation of barite scale can be estimated based on the different rates of decay of ${ }^{226} \mathrm{Ra}$ and ${ }^{228} \mathrm{Ra}$, or based on the buildup of radioactive decay products of these radium isotopes. Such information is useful for determining the sources and history of contamination at a site and for assigning possible liability.

\section{Current Status and Future Direction of the Oil-Field NORM Issue}

The magnitude of the oil-field NORM problem in the U.S. has been estimated, but it remains to be completely assessed. Increased industry awareness and understanding of the problem coupled with government regulatory efforts have provided much better control of oil-field NORM wastes and have reduced the radiation exposure to workers and the public. Management of the present inventory of stored oil-field NORM waste and options for its disposal are designed to reduce radiation hazard to the general public. The challenge to the oil and gas industry will be to develop safer and more cost-effective methods to minimize, process, and dispose of future oil-field NORM. An additional challenge to industry and government is to identify, remediate, and if necessary, remove NORM contamination that remains at old or abandoned petroleum production sites.

NORM CONCENTRATION LIMIT

$\begin{array}{cccc}\text { Licensed } & \text { Low- } & \text { Plugged } & \\ \text { NORM } & \text { level } & \text { and } & \\ \text { disposal } & \text { waste } & \text { Surface } & \text { Injection } \\ \text { abandoned Hydraulic } & \text { Salt }\end{array}$

\begin{tabular}{|c|c|c|c|c|c|c|c|}
\hline $\begin{array}{c}\text { Oil } \\
\text { industry } \\
\text { landfill }\end{array}$ & $\begin{array}{l}\text { NORM } \\
\text { disposal } \\
\text { facility }\end{array}$ & $\begin{array}{c}\text { level } \\
\text { waste } \\
\text { facility }\end{array}$ & $\begin{array}{l}\text { Surface } \\
\text { mine }\end{array}$ & $\begin{array}{l}\text { Injection } \\
\text { well }\end{array}$ & $\begin{array}{l}\text { and } \\
\text { abandoned } \\
\text { wells }\end{array}$ & $\begin{array}{l}\text { Hydraulic } \\
\text { fracture }\end{array}$ & $\begin{array}{c}\text { Salt } \\
\text { dome }\end{array}$ \\
\hline
\end{tabular}

